\title{
Importance of individual analysis of environmental and climatic factors affecting the density of Leishmania vectors living in the same geographical area: the example of Phlebotomus ariasi and P. perniciosus in northeast Spain
}

\author{
Cristina Ballart ${ }^{1,2}$, Irene Guerrero ${ }^{3}$, Xavier Castells ${ }^{4}$, Sergio Barón ${ }^{5}$, Soledad Castillejo ${ }^{1,2}$, \\ M. Magdalena Alcover ${ }^{1,2}$, Montserrat Portús ${ }^{1}$, Montserrat Gállego ${ }^{1,2}$

\begin{abstract}
${ }^{1}$ Laboratori de Parasitologia, Facultat de Farmàcia, Universitat de Barcelona, Barcelona, Spain; ${ }^{2}$ Barcelona Center for International Health Research (CRESIB), Barcelona, Spain; ${ }^{3}$ Departamento de Ecología, Facultad de Ciencias, Universidad Autónoma de Madrid, Madrid, Spain; ${ }^{4}$ Servei de Genòmica i Bioinformàtica, Parc de Recerca UAB MRB-IBB, Universitat Autònoma de Barcelona, Cerdanyola del Vallès, Spain; ${ }^{5}$ Departamento de Parasitología, Facultad de Farmacia, Universidad de Granada, Campus Universitario Cartuja, Granada, Spain
\end{abstract}

\begin{abstract}
The aim of the present study was to determine the role of specific environmental and climatic factors affecting the distribution and density of Phlebotomus ariasi and P. perniciosus, the proven vectors for Leishmania infantum in Spain. An entomological study was carried out in July 2006 in the province of Lleida with sticky traps set in their diurnal resting places at altitudes ranging from 86 to $1,755 \mathrm{~m}$ above the mean sea level (339 sites were sampled). Bivariate analysis revealed that factors such as altitude, bioclimatic zone, temperature, precipitation, sampling site (site relative to settlement, site situation, site category), wall vegetation, particular environment (in this case a natural park), general environment, adjacent natural vegetation and land cover were significantly associated with sand fly densities. The multivariate model for P. perniciosus revealed that its density was affected by site and land cover. Specifically, paved driveways correlated negatively with vector density (Incidence Risk Ratio (IRR): 0.41) and arable land cover correlated positively (IRR: 4.59). In the case of P. ariasi, a significant correlation was observed with the altitude and bioclimatic zone, with density increasing at $>800 \mathrm{~m}$ above the mean sea level (IRR: 3.40) and decreasing in the meso-Mediterranean bioclimatic zone (IRR: 0.08). Both species were mostly found in agricultural and forest areas far from domestic environments. However, the two species correlated differently with altitude, bio-climate, vegetation, temperature and precipitation, which emphasises the importance of their individual analysis in studies regarding risk of leishmaniasis transmission.
\end{abstract}

Keywords: Phlebotomus ariasi, Phlebotomus perniciosus, environmental factors, climatic factors, leishmaniasis, Spain.

Introduction

Leishmaniasis, one of the world's most neglected diseases (WHO, 2010), is a parasitic disease affecting man and other mammals. It is transmitted by the bite of female phlebotomine sand flies (Molina et al., 1994; Morillas et al., 1996; Killick-Kendrick, 1999; Ashford, 2000; Gállego, 2004). In Mediterranean European foci, leishmaniasis is caused by Leishmania infantum, and the domestic dog is the main reservoir host. Proven vectors are Phlebotomus sand flies belonging

Corresponding author:

Montserrat Gállego

Laboratori de Parasitologia

Facultat de Farmàcia, Universitat de Barcelona

Avda. Joan XXIII s/n, 08028-Barcelona, Spain

Tel. +34 93402 4502; Fax +3493 4024504

E-mail: mgallego@ub.edu to the subgenus Larroussius: P. ariasi, P. perniciosus, P. neglectus, P. perfiliewi and P. tobbi (KillickKendrick, 1999; Ready, 2010; WHO, 2010; Maroli et al., 2013). In Spain the vectorial capacity has been demonstrated for two species, P. ariasi and P. perniciosus (Rioux et al., 1986; Morillas et al., 1996; Portús et al., 2007). Until the 1980s, it was suspected that only one species was responsible for Leishmania transmission in a specific focus, but in Spain and Portugal it has been demonstrated that P. perniciosus and $P$. ariasi share the vectorial role in the same geographical areas (Pires, 1984; Rioux et al., 1986).

Studies carried out on the richness of sand fly species in Spain have identified 10 species of the Phlebotomus genus and two of Sergentomyia. One species is endemic to the Canary Islands (P. fortunatarum), where $S$. fallax has also been found, three are present only in the southern parts of the Iberian Peninsula (P. alexan- 
dri, P. chabaudi, P. riouxi), one is found in the center and the north (P. langeroni), while one is exclusive to the northeast (P. mascittii) (Gil Collado et al., 1989; Gállego Berenguer et al., 1992; Depaquit et al., 1998; Pesson et al., 2004; Barón et al., 2008). The others (P. papatasi, P. ariasi, P. perniciosus, P. sergenti, $S$. minuta) have the widest distribution. This focalised geographical distribution has been related with climatic and environmental characteristics, but only a few studies have investigated in-depth the influence of such variables on the local distribution of sand flies (Gálvez et al., 2010a; Barón et al., 2011).

Anthropic factors, including demographic pressure, urbanisation and exploitation of land for agriculture, have been thought to affect leishmaniasis distribution (Desjeux, 2001; Gállego, 2004; Colwell et al., 2011). The opportunistic character of L. infantum and coinfections with the human immunodeficiency virus (HIV) have influenced the re-emergence of the disease (Ashford, 2000). Also, changes in precipitation and temperature regimes related to climate change are thought to have impacted its distribution (de La Rocque et al., 2008; Ready, 2010; WHO, 2010; Maroli et al., 2013). Long-term climate change could lead to suitable conditions for the occurrence of sand fly species in areas previously free of them (Kuhn, 1999; Aspöck et al., 2008; Ready, 2010) and for the expansion of leishmaniasis and its sand fly vectors (Rispail et al., 2002; Maroli et al., 2008; Ready, 2008; WHO, 2010).

The presence of vectors in areas currently free of leishmaniasis is considered to pose a significant risk for the emergence of the disease in temperate Europe (Ready, 2010). Nevertheless, few studies have been published regarding the factors influencing the development of the L. infantum life cycle in proven vectors such as P. ariasi (Rioux et al., 1985). However, environmental and climatic factors affecting the presence and density of vectors have been reported recently (Gálvez et al., 2010a; Barón et al., 2011; Ozbel et al., 2011).

In recent years, an increase in canine leishmaniasis has been observed in central and southern Spain (Martin-Sánchez et al., 2009; Gálvez et al., 2010b) as well as the presence of the disease also in the north (Amusategui et al., 2004; Miró et al., 2012), including the Pyrenean region of Lleida province (Ballart et al., 2013). However, only one partial entomological survey has been carried out in the latter area (Gállego et al., 1990) and no data on the factors influencing the distribution of leishmaniasis vectors in this region are available. The aim of the present study was to deter- mine the roles of specific environmental and climatic factors in the density and distribution of sand fly species, particularly the leishmaniasis vectors and consequently the possible spread of the disease in Lleida province.

\section{Materials and methods}

\section{Study area}

The province of Lleida is situated in the northeast of Spain (Catalonia) bordering Andorra and France in the north. It covers $12,173 \mathrm{~km}^{2}$ and had a population of 470,496 inhabitants in 2006 (IDESCAT Institut d'Estadística de Catalunya; http://www.idescat.cat). The area is is divided into 13 administrative divisions (counties) and delimited by four fixed corners situated at $42^{\circ} 51.7^{\prime} \mathrm{N}, 0^{\circ} 42.5^{\prime} \mathrm{E}$; $41^{\circ} 16.5^{\prime} \mathrm{N}, 0^{\circ} 25.5^{\prime} \mathrm{E}$; $42^{\circ}$ 18.4' N, $1^{\circ} 50.6^{\prime} \mathrm{E}$; and $41^{\circ} 40.3^{\prime} \mathrm{N}, 0^{\circ} 19.3^{\prime} \mathrm{E}$ (Fig. 1). The altitude ranges widely from just over the mean sea level (MSL) to 3,143 m, which results in notable differences in variables like temperature, rainfall, vegetation, etc. and thus covers a great variety of potential sand fly habitats. As further seen in Fig. 1, the climate varies from Mediterranean, high-mountain weather in the north to continental in the central depression and is defined by six bioclimatic zones: meso-Mediterranean and supra-Mediterranean in the Ebro basin (Mediterranean region) and montane, subalpine, alpine and coline in the Pyrenees (Medioeuropean region) (Rivas-Martínez, 1983).

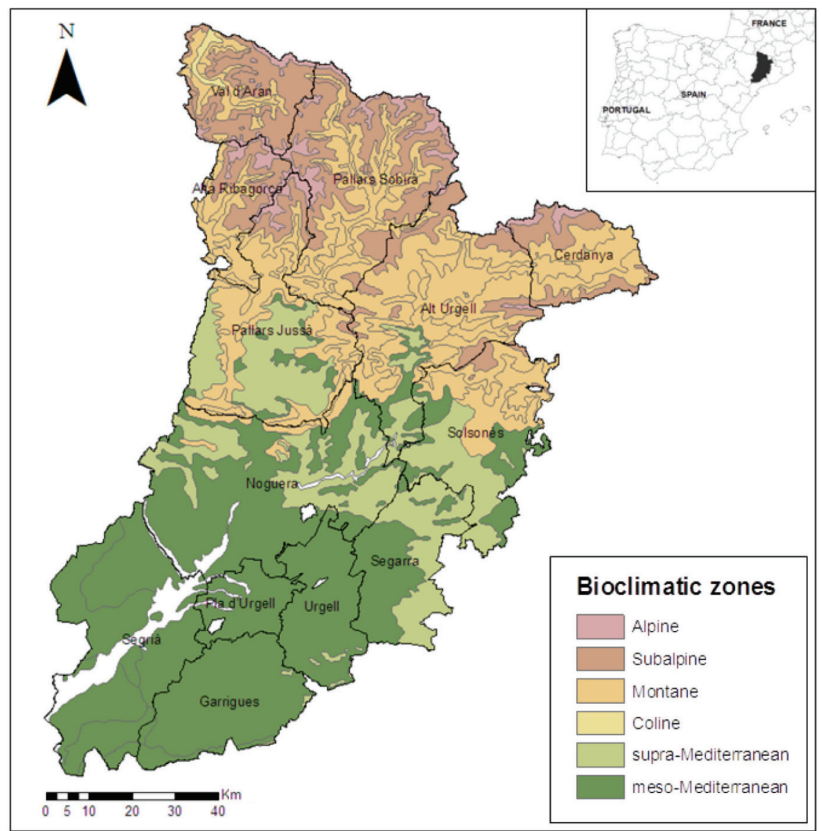

Fig. 1. The Lleida province: counties and bioclimatic zones. 
Table 1. Baseline information for the different counties of Lleida province.

\begin{tabular}{lccrrr}
\hline County & $\begin{array}{c}\text { Points } \\
\text { surveyed }\end{array}$ & $\begin{array}{c}\text { Traps } \\
\text { recovered }\end{array}$ & $\begin{array}{c}\text { Adhesion } \\
\text { surface }\left(\mathrm{m}^{2}\right)\end{array}$ & $\begin{array}{r}\text { Altitude } \\
\text { range }(\mathrm{m})\end{array}$ & $\begin{array}{c}\text { Geographical } \\
\text { coordinates }\end{array}$ \\
\hline Alt Urgell & 42 & 535 & 42.8 & $400-1,700$ & $42^{\circ} 21.5^{\prime} \mathrm{N} ; 1^{\circ} 27.8^{\prime} \mathrm{E}$ \\
Alta Ribagorça & 13 & 187 & 15.0 & $800-1,600$ & $42^{\circ} 24.6^{\prime} \mathrm{N} ; 0^{\circ} 44.6^{\prime} \mathrm{E}$ \\
Garrigues & 35 & 442 & 35.4 & $200-800$ & $41^{\circ} 31.3^{\prime} \mathrm{N} ; 0^{\circ} 52.2^{\prime} \mathrm{E}$ \\
La Cerdanya & 2 & 40 & 3.2 & $900-1,000$ & $42^{\circ} 26.0^{\prime} \mathrm{N} ; 1^{\circ} 55.7^{\prime} \mathrm{E}$ \\
Noguera & 30 & 280 & 22.4 & $200-1,000$ & $41^{\circ} 47.5^{\prime} \mathrm{N} ; 0^{\circ} 48.5^{\prime} \mathrm{E}$ \\
Pallars Jussà & 33 & 484 & 38.7 & $300-1,500$ & $42^{\circ} 10.1^{\prime} \mathrm{N} ; 0^{\circ} 53.8^{\prime} \mathrm{E}$ \\
Pallars Sobirà & 43 & 529 & 42.3 & $500-1,400$ & $42^{\circ} 24.7^{\prime} \mathrm{N} ; 1^{\circ} 07.9^{\prime} \mathrm{E}$ \\
Pla d'Urgell & 1 & 14 & 1.1 & $200-300$ & $41^{\circ} 37.9^{\prime} \mathrm{N} ; 0^{\circ} 53.8^{\prime} \mathrm{E}$ \\
Segarra & 36 & 275 & 22.0 & $300-800$ & $41^{\circ} 40.2^{\prime} \mathrm{N} ; 1^{\circ} 16.4^{\prime} \mathrm{E}$ \\
Segrià & 24 & 287 & 3.4 & $0-500$ & $41^{\circ} 37.2^{\prime} \mathrm{N} ; 0^{\circ} 37.6^{\prime} \mathrm{E}$ \\
Solsonès & 31 & 379 & 20.5 & $600-1,400$ & $41^{\circ} 59.8^{\prime} \mathrm{N} ; 1^{\circ} 31.3^{\prime} \mathrm{E}$ \\
Urgell & 28 & 256 & $600-1,800$ & $42^{\circ} 42.2^{\prime} \mathrm{N} ; 0^{\circ} 47.8^{\prime} \mathrm{E}$ \\
Vall d'Aran & 21 & 4,100 & $0-1,800$ & $4^{\circ}$ \\
Total & 339 & & &
\end{tabular}

\section{Sand fly collection and identification}

A cross-sectional study was carried out in July 2006. Sand flies were captured using sticky traps $(20 \times 20 \mathrm{~cm}$ sheets of paper covered with castor oil) set in their diurnal resting places (Rioux et al., 1969) and recovered after 4 days. Due to the extent and physical characteristics of the region, the traps were positioned along transects following the main roads in order to cover as much territory as possible (Rioux et al., 1969). A total of 4,100 sticky traps were recovered from 339 stations (Table 1). The specimens were removed with a brush and fixed in $95^{\circ}$ ethanol for 2 days in order to dissolve the oil and were then definitively conserved in $70^{\circ}$ ethanol until identification on the basis of morphological characters according to Gállego Berenguer et al. (1992). Males of all species and Sergentomyia minuta females were identified with a stereo microscope and Phlebotomus females were mounted in Hoyer's medium and identified with an optical microscope.

\section{Environmental and meteorological variables}

The characteristics of the stations were recorded in a PDA (Palm Tungsten T5) using Pendragon Form version 5.0 software (PSC; Libertyville, USA) and a global positioning system (GPS) (Tom Tom Wireless GPS MK II) (Table 2). Maps were designed using ArcGIS version 9.2 software (ESRI; Redlands, USA). Temperature and rainfall data were provided by the Servei Meteorològic de Catalunya (MeteoCat) from the 40 meteorological stations existing in the area. Data from the closest meteorological station were assigned for each sampling site using the ArcGis spatial join-and-relate tool and included temperature and precipitation mean values for different periods (see the appendix). Precipitation for the sampling period (day-1 to day-4) was introduced as a dichotomous variable (presence/absence). Altitude data for each geocoded collection site were extracted from a $90 \mathrm{~m}$ resolution CGIAR Digital Elevation Model (Jarvis et al., 2008). In the same way, a $2.5 \mathrm{~m}$ resolution CORINE shape from the CNIG (Centro Nacional de Información Geográfica) was used to extract the land cover as well as the bioclimatic zone associated with each sampling site (Rivas Martínez, 1983).

The total set of variables considered in relation to location, collection method, habitat, environment and fauna are listed in Table 2.

\section{Statistical analysis}

The abundance of sand fly species was estimated as densities (number of sand flies per $\mathrm{m}^{2}$ trap) (Gálvez et al., 2010a; Ozbel et al., 2011). The factors and categories considered are shown in the appendix. The effect of different variables on the density of $P$. perniciosus and $P$. ariasi was assessed by generalised linear models based on negative binomial distribution. All computations were performed using $\mathrm{R}$ free software ( $\mathrm{R}$ Development Core Team, 2012) and the function glm.nb, which is available in the MASS package. The exponential transformation of estimates provided by these models can be understood as an incidence risk ratio (IRR) as was discussed and interpreted in a previous study (Gálvez et al., 2010a). Thus, the IRR approach derived from our models describes how like- 
Table 2. Sampling site variables.

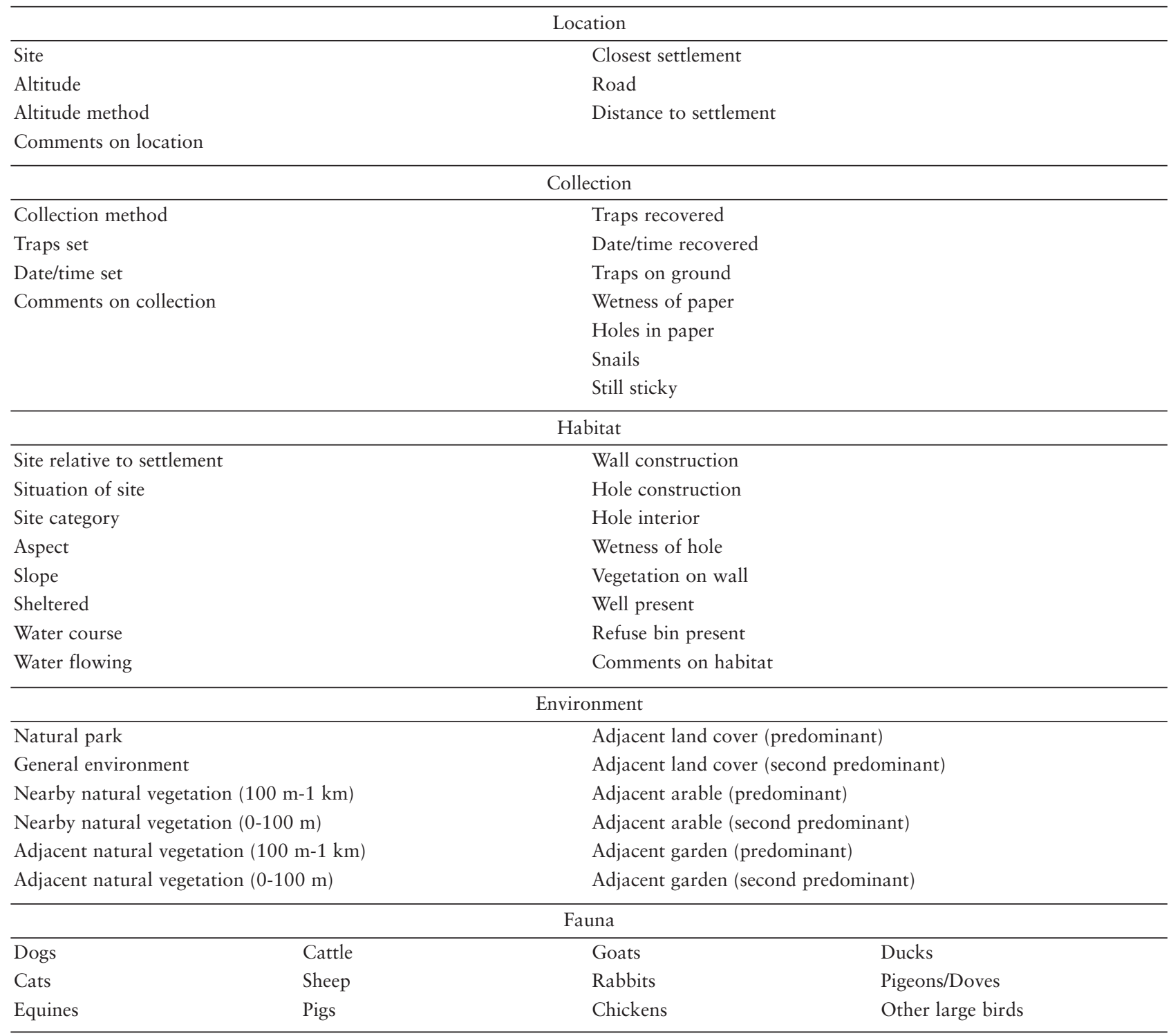

ly it is to find the vector in a given factor level compared to the reference level. For continuous variables, the IRR was interpreted in the same way but here the risk changes per unit of that variable, e.g. if an IRR equal to 1.2 is found for altitude (in meters), it means that the chances of finding the vector increases by $20 \%$ per meter. In contrast, if a factor has two levels, an IRR equal to 1.2 means that the chances of finding the vector increases by $20 \%$ in level two compared to level one. Bivariate models were computed for a set of key variables, both numerical and categorical. The statistical significance of exponential coefficients was evaluated using two tests: the probability that each coefficient differs from zero was computed through a z-statistic (McCullagh and Nelder, 1989), while a likelihood-ratio test (through a $\chi^{2}$ statistic) was performed to assess if the coefficients from a given model were different from those from the null model or, equivalently, to assess whether at least one of the estimated exponential coefficients differed from zero (McCullagh and Nelder, 1989).

Variables resulting in p-values of $<0.2$ in the bivariate analysis were selected to fit a multivariate model for each vector (Gálvez et al., 2010a; Ballart et al., 2013). In the case of closely correlated variables (temperature and precipitation) that could potentially create interaction or confusion in the multivariate analysis, we retained those from the sampling period (mean daily temperature and daily precipitation of Sampling Day 1 (traps set) to Day 4 (traps recovered)). The variables resulting in P-values of $\leq 0.05$ were considered statistically significant. 
Table 3. Baseline information for sand flies captured in Lleida province.

\begin{tabular}{lccccc}
\hline Species & $\begin{array}{c}\text { Number } \\
\text { of flies }\end{array}$ & $\begin{array}{c}\text { Sex } \\
\text { ratio }^{\mathrm{a}}\end{array}$ & $\begin{array}{c}\text { Relative } \\
\text { abundance }^{\mathrm{b}}\end{array}$ & $\begin{array}{c}\text { Relative } \\
\text { frequency }^{\mathrm{c}}\end{array}$ & Density $^{\mathrm{d}}$ \\
\hline Phlebotomus ariasi & 330 & $1: 3$ & 2.6 & 22.7 & 1.0 \\
Phlebotomus perniciosus & 1,491 & $1: 3$ & 11.7 & 40.7 & 4.5 \\
Phlebotomus sergenti & 52 & $1: 2$ & 0.4 & 4.7 & 0.2 \\
Phlebotomus papatasi & 253 & $1: 1$ & 2.0 & 11.5 & 0.8 \\
Sergentomyia minuta & 10,651 & $1: 1$ & 83.4 & 47.2 & 32.5 \\
Total & 12,777 & $1: 1$ & - & - & 39.0 \\
\hline
\end{tabular}

${ }^{\mathrm{a}}$ Female to male; 'relative number of species related to the total number of sand flies captured $(\%)$; ' relative number of positive stations related to the total number of stations sampled $(\%)$; ${ }^{d}$ number of specimens captured per $\mathrm{m}^{2}$ sticky trap.

\section{Results}

\section{Descriptive analysis}

A total of 12,777 sand fly specimens were captured, out of which material five species were identified. Information on the number of specimens captured, sex ratio, relative abundance, frequency and density are provided in Table 3. In the present study, the leishmaniasis vectors $P$. ariasi and P.perniciosus were captured in 10 and 11, respectively, out of the 13 administrative divisions of the province. $P$. ariasi was present at altitudes from 273 to $1,620 \mathrm{~m}$ above the MSL, and P. perniciosus from 94 to $1,630 \mathrm{~m}$ above the MSL (Fig. 2 ). In the present study, P. perniciosus was detected in 138 sampling sites $(41 \%)$ with a density of 4.5 specimens $/ \mathrm{m}^{2}$, while P. ariasi was present in $77(23 \%)$ showing the low density of only 1 specimen $/ \mathrm{m}^{2}$.

\section{Bivariate analysis}

The results obtained in the bivariate analysis of factors associated with P. perniciosus and P. ariasi densities are shown in the appendix. Statistically significant results $(P$ $\leq 0.05$ ) were found for both species, which were affected differently by the factors. The density of P. perniciosus was positively correlated with the following variables: bioclimatic zones, temperature, site relative to settlement, situation of sites, site category and adjacent natural vegetation. A negative correlation was found for: altitude, precipitation and the fact of being a natural park environment. The density of $P$. ariasi was positively correlated with: altitude, precipitation, site relative to settlement, wall vegetation, the fact of being a natural park environment, general environment, adjacent natural vegetation and the corine land cover. The density was negatively correlated with bioclimatic zones and temperature.

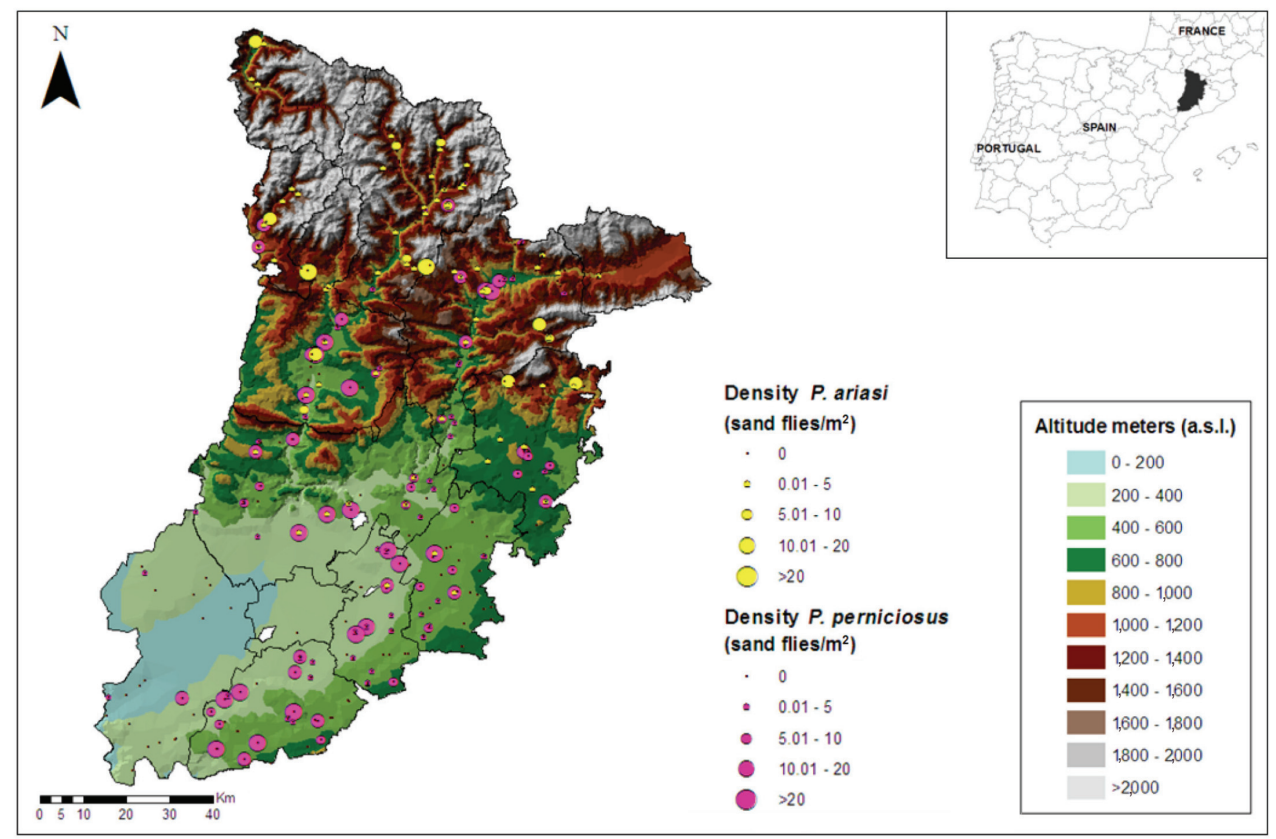

Fig. 2. Density of $P$. ariasi and P. perniciosus at different altitudinal ranges in the counties of Lleida province. 


\section{Multivariate analysis}

The final model for P. perniciosus revealed that the site situation and corine land cover affect vector density, specifically paved driveway correlated negatively (IRR: 0.41) and arable land cover correlated positively (IRR: 4.59) (Table 4). In the case of P. ariasi, the altitude and bioclimatic zone displayed a significant correlation with vector density increasing over $800 \mathrm{~m}$ (IRR: 3.40) and decreasing in the meso-Mediterranean bioclimatic zone (IRR: 0.08) (Table 4).

\section{Discussion}

The motivation to extend the entomological survey in 1987 by Gállego et al. (1990) to cover the whole province is the lack of subsequent studies after 1987 despite human leishmaniasis cases appearing in the official epidemiological bulletins (http:/gencat.cat/ salut/depsalut; Ballart et al., 2012a). In the present study, despite the increased number of sampling sites, we did not come across any species not previously found there. As in other Spanish areas, the species captured in the greatest number was S. minuta followed by the vector P. perniciosus (Martínez-Ortega, 1985; Morillas et al., 1996; Gálvez et al., 2010a). These two ubiquitous species are found in a wide variety of zones ranging from semi-arid to sub-humid (Martínez Ortega, 1985; Gállego et al., 1990; Aransay et al., 2004; Rioux, 2006) and from up to $1,500 \mathrm{~m}$ above MSL (Ballart et al., 2012b), which would explain the high degree of detection in our study. Nevertheless, it should be taken into account that results can be influenced by the method of capture, especially in the case of $P$. ariasi, the other L. infantum vector in the Iberian Peninsula that, due to its phototropism, shows a higher abundance when light traps, as CDC traps from the Centers for Disease Control and Prevention (CDC) in the US, are used (Gállego Berenguer et al., 1992; Portús et al., 2007). Of the other two species, P. papatasi has an affinity for per-arid and arid climates, which are present throughout the mesogen area of the Palaearctic region, while P. sergenti prefers semi-arid and arid zones of the Mediterranean regions (Gállego et al., 1990; Aransay et al., 2004; Boussaa et al., 2010).

In general, the use of sticky traps influences not only the relative abundance of different species captured, but also the sex ratio providing more Phlebotomus males than females (Gállego Berenguer et al., 1992; Boussaa et al., 2010) or the opposite in the case of $S$. minuta, which is probably due to its feeding (her-

Table 4. Estimates of the multivariate linear model based on the negative binomial distribution.

\begin{tabular}{|c|c|c|c|}
\hline \multirow{2}{*}{ Variable } & \multicolumn{3}{|c|}{ Multivariate analysis } \\
\hline & $\mathrm{IRR}^{\mathrm{a}}$ & $(95 \% \mathrm{CI})^{\mathrm{b}}$ & P-value \\
\hline \multicolumn{4}{|l|}{ Phlebotomus perniciosus } \\
\hline \multicolumn{4}{|l|}{ Situation of site } \\
\hline Paved road & Ref.c & & \\
\hline Paved drive & 0.41 & $(0.19-0.88)$ & 0.022 \\
\hline Unpaved track & 1.32 & $(0.58-2.99)$ & 0.492 \\
\hline Other & 0.89 & $(0.42-1.92)$ & 0.766 \\
\hline \multicolumn{4}{|l|}{ Corine land cover } \\
\hline Rural, industrial or commercial area & Ref.c & & \\
\hline Arable & 4.59 & $(1.79-11.76)$ & 0.001 \\
\hline Pasture & 3.58 & $(0.87-14.63)$ & 0.075 \\
\hline Garrigue shrubs & 3.78 & $(0.95-14.95)$ & 0.057 \\
\hline Forestry & 1.62 & $(0.39-6.69)$ & 0.502 \\
\hline \multicolumn{4}{|l|}{ Phlebotomus ariasi } \\
\hline \multicolumn{4}{|l|}{ Altitude } \\
\hline$<800 \mathrm{~m}$ & Ref.c $^{c}$ & & \\
\hline$\geq 800 \mathrm{~m}$ & 3.40 & $(1.15-10.05)$ & 0.026 \\
\hline \multicolumn{4}{|l|}{ Bioclimatic zones } \\
\hline Other & Ref.c & & \\
\hline Supra-Mediterranean & 1.12 & $(0.35-3.57)$ & 0.844 \\
\hline Meso-Mediterranean & 0.08 & $(0.02-0.39)$ & 0.001 \\
\hline
\end{tabular}

${ }^{\mathrm{a}}$ Risk ratio; ${ }^{\mathrm{b}} 95 \%$ confidence intervals; ' $\mathrm{c}$ reference category.

Variables with a P-value $\leq 0.05$ were considered significant. 
petophilic) and breeding habits (Martínez Ortega, 1985; Gil Collado et al., 1989; Gállego Berenguer et al. 1992; Boussaa et al., 2010; Gálvez et al., 2010a).

The results obtained show that the two vector species of $L$. infantum are present in Lleida province. Neither species was found in the Pla d'Urgell county, where it was only possible to sample one station. P. ariasi was not present in the southern counties (Garrigues and Segrià), probably because this species mainly inhabits humid or sub-humid zones with cold winters (Martínez Ortega, 1985; Gállego et al., 1990; Rispail et al., 2002; Aransay et al., 2004; Rioux, 2006), while P. perniciosus was not found in Vall d'Aran, which is the coldest and wettest county of Lleida province.

Several studies have recently reported the influence of environmental and climatic conditions on the distribution of leishmaniasis vectors (Rossi et al., 2007; Gálvez et al., 2010a; Ozbel et al., 2011; Queiroz et al., 2012; Branco et al., 2013). This study is the first to show the effect of these variables separately on $P$. ariasi and P. perniciosus living in sympatric conditions when captured with sticky traps in a given region showing a great variation of environmental conditions. As could be observed in the bivariate analysis, the only factors to influence the density and distribution of both vectors were site relative to settlement, general environment and corine land cover, while the other variables affected the two species differently.

P. perniciosus showed a wide altitudinal range and though present in all the bioclimatic zones was found mainly $<800 \mathrm{~m}$ above MSL, showing a preference for meso-Mediterranean and supra-Mediterranean bioclimates $(70 \%$ of the positive stations were in the Mediterranean region), as reflected in the bivariate analysis (see the appendix). In contrast, P. ariasi, which was present at altitudinal ranges similar to P. perniciosus, was found $>800 \mathrm{~m}$ above MSL and in coline, subalpine and montane bioclimates $73 \%$ of the positive stations were in the Medioeuropean region). In the multivariate analysis (see Table 4), only altitude and bioclimatic zones were significantly correlated with P. ariasi, whose density increased 3.4-fold $>800 \mathrm{~m}$ above MSL (and decreased 0.08-fold at the meso-Mediterranean level). Since other researchers have studied both species together and in bioclimatic zones that do not exactly match those of our study, no data are available for comparison (Gálvez et al., 2010a; Barón et al., 2011). It is generally accepted that altitude and bioclimate, two closely related variables, have an influence on sand fly distribution (Ferreira et al., 2001; Guernaoui et al., 2006; Gálvez et al., 2010a;
Barón et al., 2011; Ballart et al., 2012b), and that the two Spanish leishmaniasis vectors are found along a climatic gradient ranging from humid to semi-arid (de la Rocque et al., 2008). Yet, we were able to demonstrate that the vector correlation with altitude and bioclimate differed according to whether species preference was for humid or semi-arid zones.

The variables of altitude and bioclimate are closely correlated with changes in vegetation and meteorological conditions (Elnaiem et al., 1998; Guernaoui et al., 2006; Ozbel et al., 2011). The influence of temperature has been considered not only on the biology and ecology of sand flies (rate of egg production, development of the juvenile stages, number of annual generations, feeding activity, period of activity and survival of adults), but also on the development of the parasite inside the vector (Rioux et al., 1969; Elnaiem et al., 1998; Ready, 2008; Martín Sánchez et al., 2009; Hartemink et al., 2011). Rainfall has been associated with the activity period of sand flies, particularly in some South American foci (Queiroz et al., 2012; Quintana et al., 2012). In the present study, both species were found in a similar range of climatic conditions. Thus, for example, P. perniciosus was captured at mean daily temperatures (sampling day- 1 to sampling day-4) in a range of $12.5-28.3^{\circ} \mathrm{C}$ and P. ariasi at $11.4-28.0^{\circ} \mathrm{C}$. In spite of this, the two vectors differed in their correlation with meteorological variables (temperature and rainfall). In the bivariate analysis, $P$. perniciosus increased significantly with the different temperature measures considered (see appendix) and correlated negatively with monthly and annual rainfall measures, while the opposite occurred with $P$. ariasi. The lowest temperature for $P$. ariasi activity should be about $15{ }^{\circ} \mathrm{C}$ (Ashford and Bettini, 1986) and its optimal nocturnal temperature $19-21{ }^{\circ} \mathrm{C}$ (Rioux et al., 1969), but no published data exist for P. perniciosus. In our study, we found both species at lower temperatures (mean daily temperatures of $12.5{ }^{\circ} \mathrm{C}$ and $11.4{ }^{\circ} \mathrm{C}$, respectively). However, regardless of species, none of these variables were found to be statistically significant in the multivariate analysis.

It is assumed that in temperate regions, higher temperatures may shorten larval development and extend the breeding season of existing sand flies or allow new species to become established where low temperatures have hitherto prevented their over-wintering (Maroli et al., 2008), while declining autumn temperatures, together with the shortening day, induce diapauses of fourth instar larvae (Ready and Croset, 1980). Nevertheless, conflicting results have been obtained by different authors on the influence of temperature on 
the presence, abundance or density of sand flies, depending on the species analysed or the bioclimatic area considered (Martín Sánchez et al., 2009; Chamaillé et al., 2010; Gálvez et al., 2010a). These results indicate that temperature is not the only explanation for sand fly distribution and density (Gállego, 2004; Gage et al., 2008; Colwell et al., 2011).

In the bivariate analysis, significantly higher densities of both vector species were found in the areas between villages, and in the case of $P$. perniciosus, also at the village edge, which corresponds with other studies carried out in Spain (Gálvez et al., 2010a; Barón et al., 2011). The increased presence of vectors between villages could be favoured by the higher availability of oviposition and resting sites as well as the presence of a greater variety of animals constituting potential blood meals, considering the opportunistic feeding behaviour of both species (Guy et al., 1984; de Colmenares et al., 1995; Rossi et al., 2008). In fact, in the Lleida Pyrenees area, we have found a high percentage of Leishmania seropositive dogs among the canine population living in conditions favourable for transmission (rural dogs, living in kennels and sleeping outdoors) (Ballart et al., 2013).

As shown in the bivariate and multivariate analysis, P. perniciosus was found mainly on unpaved tracks and in places such as farm properties or gardens, rather than on paved roads and driveways, which implies a preference for quiet places with food facilities, as observed by Gálvez et al. (2010a). This result corresponds with the maximum detection of $P$. perniciosus in farm buildings in a rural environment far away from villages. No significant differences were found in the case of P. ariasi, even if this species was also found preferentially far away from villages. This result could be related to the positive correlation of this species with natural parks, unlike $P$. perniciosus, probably due to a preference for more natural environments and exophilic requirements. The two species also showed different positive correlation with flora: $P$. ariasi with mountain pine and oak, while P. perniciosus preferred Aleppo pine and garrigue shrubs. This is related to their altitudinal and bioclimatic distribution, which has been described for the South of France (Rioux et al., 1969; Hartemink et al., 2011). Sand fly abundance prediction maps showing a different predominance of both species according to altitude and vegetation have been obtained in southern France, P. ariasi being predominant in the forested foothills and P. perniciosus at lower altitudes (Hartemink et al., 2011).

Other variables such as wall and hole constructions and hole interior conditions did not seem to affect the density of these vector species, in agreement with other authors (Gálvez et al., 2010a). Nevertheless, Barón et al. (2011) proposed PVC piping holes as a feasible control measure against leishmaniasis due to the decreased finding of P. perniciosus in this kind of hole construction. Unlike other reports (Coleman et al., 2007; Gálvez et al., 2010a), we found the aspect and shelter conditions of the sampling site not to be correlated with vector density. In contrast to other studies in Spain or Morocco, which found the greatest densities of these sand flies in places where livestock or birds are present (Guernaoui and Boumezzough, 2009; Gálvez et al., 2010a; Barón et al., 2011), we did not find the presence of animals associated with vector density. The presence of dogs did not favour the presence of either vector species as observed by Gálvez et al. (2010a) and Barón et al. (2011), which is surprising considering the epidemiology of the disease caused by $L$. infantum with the dog acting as a reservoir in a domestic zoonotic cycle. However, the opportunistic trophic behaviour of the vectors may have influenced these results (Guy et al., 1984; de Colmenares et al., 1995; Rossi et al., 2008).

The incrimination of a potential leishmaniasis vector in a given area has usually involved the species present in the highest density (Martínez-Ortega, 1985). Studies in Spain have concluded that the potential vector of L. infantum in this country is P. perniciosus. Densities of 4-6 specimens $/ \mathrm{m}^{2}$ are considered to imply an increased risk of leishmaniasis emergence in France and Spain (Rioux et al. 1977; Martín-Sánchez et al., 2009). In the present study, P. perniciosus showed a higher density than P. ariasi and reached the minimal density considered a risk for transmission. Nevertheless, results regarding sand fly composition species may vary depending on the sampling techniques used (Gállego Berenguer et al., 1992) and also studies on the presence of kinetoplastida in sand flies have demonstrated the vectorial capacity of $P$. ariasi populations with low densities (Rioux et al., 1986; Lucientes et al., 1988; Guilvard et al., 1996; Morillas et al., 1996). We found the two vector species together in 46 sampling sites $(14 \%)$ where they could be acting in the same geographical area in the transmission of the disease, as observed in other regions of Portugal and Spain (Pires, 1984; Rioux et al., 1986; Lucientes et al., 1988).

Leishmaniasis is a climate-sensitive disease affected by changes in rainfall, atmospheric temperature and humidity, which can strongly impact on the ecology of vectors and reservoir hosts by altering their distribution and influencing their activity, survival and popu- 
lation sizes (Elnaiem et al., 1998; Killick Kendrick, 1999; Aspöck et al., 2008; Gage et al., 2008; Ready, 2010). In the Mediterranean region, most leishmaniasis foci are between $5{ }^{\circ} \mathrm{C}$ and $10{ }^{\circ} \mathrm{C}$ in January isotherms and between $20{ }^{\circ} \mathrm{C}$ and $30{ }^{\circ} \mathrm{C}$ in July (Ashford and Bettini, 1986). Relatively small changes in temperature can have a considerable effect on vectorial capacity, due to alterations in the frequency of bloodmeals (Ready, 2010) and the development cycle of Leishmania promastigotes in sand flies (Rioux et al., 1985). Precipitation determines sand fly survival and promotes adult emergence and appropriate oviposition sites (Gage et al., 2008). In this study, P. ariasi and $P$. perniciosus differed in their correlation with temperature, precipitation, altitudinal and bioclimatic zones and vegetation. While P.perniciosus is considered the principal potential vector of leishmaniasis in the southern area of Lleida, P. ariasi could play this role in the northern, Pyrenean region. In fact, we have previously found $L$. infantum DNA in $P$. ariasi specimens (Alcover et al., 2012) and demonstrated the existence of an autochthonous focus of canine leishmaniasis in this area (Ballart et al., 2012a, 2013).

Global climate change could alter the dynamics of leishmaniasis transmission, leading to variation in distribution, emergence or re-emergence. It would thus be of interest to analyse how the present results on vector distribution and density could be affected by climate change, considering that Spain is undergoing trend of increasing temperatures $\left(3.7^{\circ} \mathrm{C} / 100\right.$ years $)$ based on the 1980-2006 period (Brunet et al., 2009). A related issue that needs to beaddressed is the hypothesis of an extension of P. perniciosus towards northern areas as this region aquires more tolerable summer temperatures, while it undergoes a decline in the South (Kuhn, 1999). There could also be an increase in the activity period and vectorial competence of $P$. ariasi in northern areas. Observations in that direction have been made in the centre and southern parts of Spain (Martín Sánchez et al., 2009; Gálvez et al., 2010a). This study could be the basis of future research on mapping the establishment risk for emerging leishmaniasis in the study area as has been done in Europe and South America (Hartemink et al., 2011; Foley et al., 2012).

\section{Conclusions}

The bivariate analysis provided information about the risk factors affecting the density of $P$. ariasi and $P$. perniciosus. Both species were found mainly in agricultural areas and forests far from the domestic environment. However, the two species correlated differ- ently with altitude, bioclimate, vegetation, temperature and precipitation, which emphasises the importance of their individual analysis with regard to the risk of leishmaniasis transmission. A constant monitoring of sand fly vectors in new leishmaniasis foci is crucial for evaluating the geographical expansion of the disease. Studies on the parasitism of these species are required to gain more insight into their involvement in the transmission of L. infantum in Lleida province.

\section{Acknowledgements}

This work was supported by grants of the Ministerio de Educación y Ciencia of Spain (AGL2004-06909-C02-01), Departament d'Universitats, Recerca i Societat de la Informació de la Generalitat de Catalunya (Spain) (2009SGR385) and European Union (GOCE-2003-010284 EDEN, Emerging Diseases in a changing European eNvironment, www.edenfp6project.net). Thanks are due to Dr. MartínSanchez for reviewing the manuscript and for her helpful comments and to the Servei de Meteorologia de Catalunya that has provided the meteorological data for the study. Maria Rubio and Ester Cantó contributed to the field work capturing sand flies. $\mathrm{CB}$ was awarded a PhD student grant of the EDEN project. The contents of this publication are the sole responsibility of the authors and do not necessarily reflect the views of the European Commission.

\section{References}

Alcover MM, Gramiccia M, Di Muccio T, Ballart C, Castillejo S, Picado A, Bongiorno G, Portús M, Gállego M, 2012. Application of molecular techniques in the study of natural infection of Leishmania infantum vectors and utility of sandfly blood meal digestion for epidemiological surveys of leishmaniasis. Parasitol Res 111, 515-523.

Amusategui I, Sainz A, Aguirre E, Tesouro MA, 2004. Seroprevalence of Leishmania infantum in Northwestern Spain, an area traditionally considered free of leishmaniasis. Ann N Y Acad Sci 1026, 154-157.

Aransay AM, Testa JM, Morillas-Márquez F, Lucientes J, Ready PD, 2004. Distribution of sandfly species in relation to canine leishmaniasis from the Ebro Valley to Valencia, northeastern Spain. Parasitol Res 94, 416-420.

Ashford RW, 2000. The leishmaniases as emerging and reemerging zoonoses. Int J Parasitol 30, 1269-1281.

Ashford RW, Bettini S, 1987. Ecology and epidemiology: Old World. In: The leishmaniasis in biology and medicine I. Biology and epidemiology. Peters W, Killick-Kendrick R (eds). Academic Press, London, 500 pp.

Aspöck H, Gerersdorfer, T, Formayer H, Walochnik J, 2008. 
Sand flies and sand fly-borne infections of humans in Central Europe in the light of climate change. Wien Klin Wochenschr 120, 24-29.

Ballart C, Alcover MM, Picado A, Nieto J, Castillejo S, Portús M, Gállego M, 2013. First survey on canine leishmaniasis in a non classical area of the disease in Spain (Lleida, Catalonia) based on a veterinary questionnaire and a cross-sectional study. Prev Vet Med 109, 116-127.

Ballart C, Alcover MM, Portús M, Gállego M, 2012a. Is leishmaniasis widespread in Spain? First data on canine leishmaniasis in the province of Lleida, Catalonia, northeast Spain. Trans R Soc Trop Med Hyg 106, 134-136.

Ballart C, Barón S, Alcover MM, Portús M, Gállego M, 2012b. Distribution of phlebotomine sand flies (Diptera: Psychodidae) in Andorra: first fnding of P. perniciosus and wide distribution of P. ariasi. Acta Trop 122, 155-159.

Barón S, Martín-Sánchez J, Gállego M, Morales-Yuste M, Boussa S, Morillas-Márquez F, 2008. Intraspecific variability (rDNA ITS and mtDNA Cyt b) of Phlebotomus sergenti in Spain and Morocco. Acta Trop 107, 259-267.

Barón SD, Morillas-Márquez F, Morales-Yuste M, Díaz-Sáez V, Irigaray C, Martín-Sánchez J, 2011. Risk maps for the presence and absence of Phlebotomus perniciosus in an endemic area of leishmaniasis in southern Spain: implications for the control of the disease. Parasitology 138, 1234-1244.

Boussaa S, Neffa M, Pesson B, Boumezzough A, 2010. Phlebotomine sandflies (Diptera: Psychodidae) of southern Morocco: results of entomological surveys along the Marrakech-Ouarzazat and Marrakech-Azilal roads. Ann Trop Med Parasitol 104, 163-170.

Branco S, Alves-Pires C, Maia C, Cortes S, Cristovão JM, Gonçalves L, Campino L, Afonso MO, 2013. Entomological and ecological studies in a new potential zoonotic leishmaniasis focus in Torres Novas municipality, Central Region, Portugal. Acta Trop 125, 339-348.

Brunet M, Casado MJ, de Castro M, Galán P, López JA, Martín JM, Pastor A, Petisco E, Ramos P, Ribalaygua J et al., 2009. Generación de escenarios regionalizados de cambio climático para España. In: Agencia Estatal de Meteorología. Ministerio de Medioambiente y Medio Rural y Marino, Gobierno de España (ed). Spain, 158 pp.

Chamaillé L, Tran A, Meunier A, Bourdoiseau G, Ready P, Dedet JP, 2010. Environmental risk mapping of canine leishmaniasis in France. Parasit Vectors 3, 31.

Coleman RE, Burkett DA, Sherwood V, Caci J, Spradling S, Jennings BT, Rowton E, Gilmore W, Bount K, White CE et al., 2007. Impact of phlebotomine sand flies on United State military operations at Tallil Air Base, Iraq 2. Temporal and geographic distribution of sand flies. J Med Entomol 44, 29-41.

Colwell DD, Dantas-Torres F, Otranto D, 2011. Vector-borne parasitic zoonoses: emerging scenarios and new perspectives. Vet Parasitol 182, 14-21. de Colmenares M, Portús M, Botet J, Dobaño C, Gállego M, Aisa MJ, Wolff M, Seguí MG, 1995. Identification of blood meals of Phlebotomus perniciosus (Diptera: Psychodidae) in Spain by a competitive enzyme-linked immunosorbent assay biotin/avidin method. J Med Entomol 32, 229-233.

de La Rocque S, Rioux JA, Slingenbergh J, 2008. Climate change: effects on animal disease systems and implications for surveillance and control. Rev Sci Tech Oie 27, 339-354.

Depaquit J, Léger N, Killick-Kendrick R, 1998. Description de Phlebotomus (Paraphlebotomus) riouxi sp. (Diptera Psychodidae) d'Afrique du Nord. Parasite 5, 151-158.

Desjeux P, 2001. The increase in risk factors for leishmaniasis worldwide. Trans R Soc Trop Med Hyg 95, 239-243.

Elnaiem DA, Connor SJ, Thomson MC, Hassan MM, Hassan HK, Aboud MA, Ashford RW, 1998. Environmental determinants of the distribution of Phlebotomus orientalis in Sudan. Ann Trop Med Parasitol 92, 877-887.

Ferreira AL, Sessa PA, Varejão JB, Falqueto A, 2001. Distribution of sand flies (Diptera: Psychodidae) at different altitudes in an endemic region of American cutaneous leishmaniasis in the State of Espírito Santo, Brazil. Mem Inst Oswaldo Cruz 96, 1061-1067.

Foley DH, Wilkerson RC, Dornak LL, Pecor DB, Nyari AS, Rueda LM, Long LS, Richardson JH, 2012. SandflyMap: leveraging spatial data on sand fly vector distribution for disease risk assessments. Geospat Health 6, 25-30.

Gage KL, Burkot TR, Eisen RJ, Hayes EB, 2008. Climate and vectorborne diseases. Am J Prev Med 35, 436-450.

Gállego Berenguer J, Botet J, Gállego M, Portús M, 1992. Los flebotomos de la España peninsular e Islas Baleares. Identificación y corología. Comentarios sobre los métodos de captura. In: In Memoriam al Prof. Dr. DF de P. Martínez Gómez. Hernández S (ed). Publicaciones de la Universidad de Córdoba, 581-600 pp.

Gállego M, 2004. Zoonosis emergentes por patógenos parásitos: las leishmaniasis. Rev Sci Tech Oie 23, 661-676.

Gállego M, Rioux JA, Rispail P, Guilvard E, Gállego J, Portús M, Delalbre A, Bastien P, Martínez-Ortega E, Fisa R, 1990. Primera denuncia de flebotomos (Diptera, Psychodidae, Phlebotominae) en la provincia de Lérida (España, Cataluña). Rev Ibér Parasitol 50, 123-127.

Gálvez R, Descalzo MA, Miró G, Jiménez MI, Martín O, Dos Santos-Brandao F, Guerrero I, Cubero E, Molina R, 2010a. Seasonal trends and spatial relations between environmental/meteorological factors and leishmaniasis sand fly vector abundances in Central Spain. Acta Trop 115, 95-102.

Gálvez R, Miró G, Descalzo MA, Nieto J, Dado D, Martín O, Cubero E, Molina R, 2010b. Emerging trends in the seroprevalence of canine leishmaniasis in the Madrid region (central Spain). Vet Parasitol 169, 327-334.

Gil Collado J, Morillas F, Sanchís MC, 1989. Los flebotomos en España. Revista de Sanidad e Higiene Pública 63, 15-34. 
Guernaoui S, Boumezzough A, 2009. Habitat preferences of phlebotomine sand flies (Diptera: Psychodidae) in Southwestern Morocco. J Med Entomol 46, 1187-1194.

Guernaoui S, Boumezzough A, Laamrani A, 2006. Altitudinal structuring of sand flies (Diptera: Psychodidae) in the HighAtlas mountains (Morocco) and its relation to the risk of leishmaniasis transmission. Acta Trop 97, 346-351.

Guilvard E, Gállego M, Moreno G, Fisa R, Rispail P, Pratlong F, Martínez-Ortega E, Gállego J, Rioux JA, 1996. Infestation naturelle de Phlebotomus ariasi et Phlebotomus perniciosus (Diptera-Psychodidae) par Leishmania infantum (Kinetoplastida-Trypanosomatidae) en Catalogne (Espagne). Parasite 3, 191-192.

Guy MW, Killick-Kendrick R, Gill GS, Rioux JA, Bray RS, 1984. Ecology of leishmaniasis in the south of France. 19. Determination of the hosts of Phlebotomus ariasi Tonnoir, 1921 in the Cévennes by bloodmeal analyses. Ann Parasitol Hum Comp 59, 449-458.

Hartemink N, Vanwambeke SO, Heesterbeek H, Rogers D, Morley D, Pesson B, Davies C, Mahamdallie S, Ready P, 2011. Integrated mapping establishment risk for emerging vectorborne infections: a case study of canine leishmaniasis in southwest France. PLoS One 6, e20817.

Jarvis A, Reuter HI, Nelson A, Guevara E, 2008. Hole-filled seamless SRTM data V4, International Centre for Tropical Agriculture (CIAT). Available at: http://srtm.csi.cgiar.org (accessed on October 2012).

Kuhn KG, 1999. Global warming and leishmaniasis in Italy. Trop Med Int Health 7, 1-2.

Killick-Kendrick R, 1999. The biology and control of phlebotomine sand flies. Clin Dermatol 17, 279-289.

Lucientes-Curdi J, Sánchez-Acedo C, Castillo Hernández JA, Estrada Peña A, 1988. Sobre la infección natural por Leishmania en Phlebotomus perniciosus Newstead, 1911, y Phlebotomus ariasi Tonnoir, 1921, en el foco de leishmaniasis de Zaragoza. Rev Ibér Parasitol 48, 7-8.

Maroli M, Feliciangeli MD, Bichaud L, Charrel RN, Gradoni L, 2013. Phlebotomine sandflies and the spreading of leishmaniases and other diseases of public health concern. Med Vet Entomol 27, 123-147.

Maroli M, Rossi L, Baldelli R, Capelli G, Ferroglio E, Genchi C, Gramiccia M, Mortarino M, Pietrobelli M, Gradoni L, 2008. The northward spread of leishmaniasis in Italy: evidence from retrospective and ongoing studies on the canine reservoir and phlebotomine vectors. Trop Med Int Health 13, 256-264.

Martín-Sánchez J, Morales-Yuste M, Acedo-Sánchez C, Barón S, Díaz V, Morillas-Márquez F, 2009. Canine leishmaniasis in southeastern Spain. Emerg Infect Dis 15, 795-798.

Martínez-Ortega E, 1985. Los flebotomos ibéricos (Diptera: Psychodidae). II. El sureste. Ann Biol 3, 113-119.

McCullagh P, Nelder JA, 1989. Generalized linear models. Chapman and Hall/CRC; Boca Raton, Florida (second edi- tion).

Miró G, Checa R, Montoya A, Hernández L, Dado D, Gálvez $\mathrm{R}, 2012$. Current situation of Leishmania infantum infection in shelter dogs in northern Spain. Parasit Vectors 5, 60.

Molina R, Amela C, Nieto J, San-Andrés M, Gónzalez F, Castillo JA, Lucientes J, Alvar J, 1994. Infectivity of dogs naturally infected whit Leishmania infantum to colonized Phlebotomus perniciosus. Trans R Soc Trop Med Hyg 88, 491-493.

Morillas F, Sánchez Rabasco F, Ocaña J, Martín-Sánchez J, Ocana-Wihelmi J, Acedo C, Sanchís-Marín MC, 1996. Leishmaniasis in the focus of the Axarquia region, Málaga province, southern Spain: a survey of the human, dog, and vector. Parasitol Res 82, 569-570.

Ozbel Y, Balcio lu IC, Olgen MK, Simsek FM, Töz SÖ, Ertabaklar H, Demir S, Alkan MZ, 2011. Spatial distribution of phlebotomine sand flies in the Aydin mountains and surroundings: the main focus of cutaneous leishmaniasis in western Turkey. J Vector Ecol 36, 99-105.

Pesson B, Ready JS, Benabdennbi I, Martín-Sánchez J, Esseghir S, Cadi-Soussi M, Morillas-Márquez F, Ready PD, 2004. Sandflies of the Phlebotomus perniciosus complex: mitochondrial introgression and a new sibling species of P. longicuspis in the Moroccan Rif. Med Vet Entomol 18, 25-37.

Pires CA, 1984. Les Phlébotomes du Portugal. I. Inféstation naturelle de Phlebotomus ariasi Tonnoir, 1921 et Phlebotomus perniciosus Newstead, 1911 par Leishmania, dans le foyer zoonotique de Arrábida (Portugal). Ann Parasitol Hum Comp 59, 521-524.

Portús M, Gállego M, Riera C, Fisa R, Aisa MJ, Botet J, Carrió J, Castillejo S, Iniesta L, López P et al., 2007. A review of human and canine leishmaniasis in Catalonia and associated vector distribution. Rev Ibér Parasitol 67, 59-67.

Queiroz MF, Varjão JR, Moraes SC, Salcedo GE, 2012. Analysis of sandflies (Diptera: Psychodidae) in Barra do Garças, State of Mato Grosso, Brazil, and the influence of environmental variables on the vector density of Lutzomyia longipalpis (Lutz and Neiva, 1912). Rev Soc Bras Med Trop 45, 313-317.

Quintana M, Salomón O, Guerra R, Lizarralde DE, Grosso M, Fuenzalida A, 2012. Phlebotomine of epidemiological importance in cutaneous leishmaniasis in northwestern Argentina: risk maps and ecological niche models. Med Vet Entomol 27, 39-48.

R Development Core Team, 2012. R: a language and environment for statistical computing. Vienna: R Foundation for Statistical Computing.

Ready PD, 2008. Leishmaniasis emergence and climate change. Rev Sci Tech Oie 27, 399-412.

Ready PD, 2010. Leishmaniasis emergence in Europe. Euro Surveill 15, 19505.

Ready PD, Croset H, 1980. Diapause and laboratory breeding of Phlebotomus perniciosus Newstead and Phlebotomus ariasi 
Tonnoir (Diptera: Psychodidae) from southern France. Bull Entomol Res 70, 511-523.

Rioux JA, 2006. Le paradigme "écopathologie” II - Son application à l'épidémiologie des leishmanioses. Académie des Sciences et Lettres de Montpellier, 35-46.

Rioux JA, Aboulker JP, Lanotte G, Killick-Kendrick R, MartiniDumas A, 1985. Écologie des leishmanioses dans le sud de la France. 21. Influence de la température sur le développement de Leishmania infantum Nicolle, 1908 chez Phlebotomus ariasi Tonnoir, 1921. Étude expérimentale. Ann Parasitol Hum Comp 3, 221-229.

Rioux JA, Croset H, Lanotte G, 1977. Écologie d'un foyer méditerranéen de leishmaniose viscérale. Essai de modélisation. Colloque International du CNRS 39, 295-305.

Rioux JA, Golvan YJ, Croset H, Tour S, Abonnenc E, Petitdidier M, Vollhardt Y, Dedet JP, Albaret JL, Lanotte G et al., 1969. Epidémiologie des Leishmanioses dans le Sud de la France. In: Monographie 37. Institut National de la Santé et de la Recherche Médicale (ed). Paris, 220 pp.

Rioux JA, Guilvard E, Gállego J, Moreno G, Pratlong F, Portús M, Rispail P, Gállego M, Bastien P, 1986. Intervention simultanée de Phlebotomus ariasi Tonnoir, 1921 et P. perniciosus Newstead 1911 dans un même foyer. Infestations par deux zymodemes syntopiques. A propos d'une enquête en Catalogne (Espagne). Leishmania: Taxonomie et Phylogenèse. Applications éco-épidémiologiques. Montpellier, IMEEE, 439444.

Rispail P, Dereure J, Jarry D, 2002. Risk zones of human leishmaniases in the Western Mediterranean basin: correlations between vector sand flies, bioclimatology and phytosociology. Mem Inst Oswaldo Cruz 97, 477-483.

Rivas-Martínez S, 1983. Pisos bioclimáticos de España. Lazaroa 5, 33-43.

Rossi E, Bongiorno G, Ciolli E, Di Muccio T, Scalone A, Gramiccia M, Gradoni L, Maroli M, 2008. Seasonal phenology, host-blood feeding preferences and natural Leishmania infection of Phlebotomus perniciosus (Diptera, Psychodidae) in a high-endemic focus of canine leishmaniasis in Rome province, Italy. Acta Trop 105, 158-165.

Rossi E, Rinaldi L, Musella V, Veneziano V, Carbone S, Gradoni L, Cringoli G, Maroli M, 2007. Mapping the main Leishmania phlebotomine vector in the endemic focus of the Mt. Vesuvius in southern Italy. Geospat Health 1, 191-198. WHO, 2010. Control of the leishmaniases: report of a meeting of the WHO expert committee on the control of leishmaniases. WHO Tech Rep Ser 949. 


\section{Appendix}

Factors studied in the cross-sectional study and results obtained with bivariate analysis.

\begin{tabular}{|c|c|c|c|c|c|c|}
\hline \multirow[b]{2}{*}{ Variable } & \multicolumn{2}{|c|}{ Sampling site } & \multicolumn{2}{|c|}{ P. perniciosus } & \multicolumn{2}{|c|}{ P. ariasi } \\
\hline & $\begin{array}{l}\text { Number of } \\
\text { sampling stations }\end{array}$ & $\begin{array}{c}\text { Percent } \\
\text { of stations }\end{array}$ & $\operatorname{IRR}^{\mathrm{a}}(95 \% \mathrm{CI})^{\mathrm{b}}$ & P-value & $\operatorname{IRR}^{\mathrm{a}}(95 \% \mathrm{CI})^{\mathrm{b}}$ & P-value \\
\hline Altitude $(\mathrm{m})^{\mathrm{c}}$ & $700(86-1,755)$ & $438-949 *$ & $0.99(0.99-0.99)$ & $<0.001$ & $1.00(1.002-1.003)$ & $<0.001$ \\
\hline \multicolumn{7}{|l|}{ Altitude (m) } \\
\hline$<800$ & 221 & $65 \%$ & Ref. category & & Ref. category & \\
\hline$\geq 800$ & 118 & $35 \%$ & $0.21(0.12-0.37)$ & $<0.001$ & $4.98(2.67-9.28)$ & $<0.001$ \\
\hline \multicolumn{7}{|l|}{ Bioclimatic zone } \\
\hline Coline, montane, subalpine & 142 & $42 \%$ & Ref. category & & Ref. category & \\
\hline Supra-Mediterranean & 76 & $22 \%$ & $2.90(1.44-5.85)$ & 0.003 & $0.43(0.22-0.87)$ & 0.019 \\
\hline Meso-Mediterranean & 121 & $36 \%$ & $3.93(2.13-7.25)$ & $<0.001$ & $0.02(0.01-0.07)$ & $<0.001$ \\
\hline \multicolumn{7}{|l|}{ Mean daily temperature $\left({ }^{\circ} \mathrm{C}\right)^{\mathrm{c}}$} \\
\hline Sampling day-1 (traps set) & $22.3(11.4-28.3)$ & $5.1 * *$ & $1.18(1.12-1.25)$ & $<0.001$ & $0.89(0.84-0.94)$ & $<0.001$ \\
\hline to day-4 (traps recovered) & $21.1(11.1-27.7)$ & $5.2 * *$ & $1.18(1.12-1.25)$ & $<0.001$ & $0.89(0.84-0.94)$ & $<0.001$ \\
\hline \multicolumn{7}{|l|}{ Mean monthly temperature $\left({ }^{\circ} \mathrm{C}\right)^{\mathrm{c}}$} \\
\hline (The month before sampling day-1) & $10.4(2.0-15.0)$ & $4.5 * *$ & $1.24(1.16-1.31)$ & $<0.001$ & $0.87(0.81-0.93)$ & $<0.001$ \\
\hline \multicolumn{7}{|l|}{ Mean annual temperature $\left({ }^{\circ} \mathrm{C}\right)^{\mathrm{c}}$} \\
\hline (The year before sampling day-1) & $-2.7(-7.3-0.3)$ & $-2.4 * *$ & $1.33(1.19-1.49)$ & $<0.001$ & $0.72(0.64-0.81)$ & $<0.001$ \\
\hline \multicolumn{7}{|l|}{ Mean minimal winter temp. $\left({ }^{\circ} \mathrm{C}\right)^{\mathrm{c}}$} \\
\hline \multicolumn{7}{|l|}{ Daily precipitation } \\
\hline Absent & 136 & $40 \%$ & Ref. category & & Ref. category & \\
\hline Present & 203 & $60 \%$ & $1.11(0.62-1.95)$ & 0.730 & $1.46(0.74-2.86)$ & 0.265 \\
\hline \multicolumn{7}{|l|}{ Mean monthly precipitation $(\mathrm{mm})^{c}$} \\
\hline (The month before sampling day-1) & $1.7(0.03-5.8)$ & $1.6^{* *}$ & $0.69(0.58-0.82)$ & $<0.001$ & $1.88(1.56-2.27)$ & $<0.001$ \\
\hline \multicolumn{7}{|l|}{ Mean annual precipitation $(\mathrm{mm})^{c}$} \\
\hline (The year before sampling day-1) & $15.2(5.2-34.1)$ & $6.7^{* * *}$ & $0.89(0.85-0.92)$ & $<0.001$ & $1.16(1.11-1.21)$ & $<0.001$ \\
\hline \multicolumn{7}{|l|}{ Site relative to settlement } \\
\hline Within & 124 & $37 \%$ & Ref. category & & Ref. category & \\
\hline Edge & 112 & $33 \%$ & $3.59(1.88-6.84)$ & $<0.001$ & $1.13(0.52-2.46)$ & 0.751 \\
\hline Between & 103 & $30 \%$ & $4.69(2.43-9.06)$ & $<0.001$ & $3.58(1.67-7.68)$ & 0.001 \\
\hline \multicolumn{7}{|l|}{ Situation of site } \\
\hline Paved road & 169 & $50 \%$ & Ref. category & & Ref. category & \\
\hline Paved drive & 60 & $18 \%$ & $1.16(0.54-2.47)$ & 0.701 & $0.60(0.24-1.48)$ & 0.268 \\
\hline Unpaved track & 44 & $13 \%$ & $2.48(1.06-5.79)$ & 0.034 & $0.36(0.12-1.03)$ & 0.057 \\
\hline Other (garden, farm property, other) & 66 & $19 \%$ & $2.36(1.14-4.88)$ & 0.020 & $0.58(0.24-1.38)$ & 0.220 \\
\hline \multicolumn{7}{|l|}{ Site category } \\
\hline Embankment & 164 & $48 \%$ & Ref. category & & Ref. category & \\
\hline Wall & 82 & $24 \%$ & $1.07(0.54-2.11)$ & 0.841 & $0.70(0.31-1.58)$ & 0.394 \\
\hline Farm building & 10 & $3 \%$ & $6.06(1.20-30.44)$ & 0.028 & $0.05(0.00-1.28)$ & 0.070 \\
\hline Other & 83 & $25 \%$ & $1.32(0.67-2.61)$ & 0.411 & $0.72(0.32-1.61)$ & 0.425 \\
\hline \multicolumn{7}{|l|}{ Aspect } \\
\hline Other (not applicable) & 24 & $8 \%$ & Ref. category & & Ref. category & \\
\hline North-facing & 93 & $27 \%$ & $0.37(0.11-1.18)$ & 0.092 & $0.76(0.18-3.09)$ & 0.708 \\
\hline East-facing & 31 & $9 \%$ & $0.45(0.11-1.78)$ & 0.255 & $1.07(0.20-5.58)$ & 0.927 \\
\hline South-facing & 156 & $46 \%$ & $0.37(0.12-1.13)$ & 0.082 & $2.62(0.70-9.81)$ & 0.150 \\
\hline West-facing & 35 & $10 \%$ & $0.60(0.15-2.27)$ & 0.451 & $1.69(0.34-8.20)$ & 0.513 \\
\hline
\end{tabular}




\begin{tabular}{|c|c|c|c|c|c|c|}
\hline \multirow[b]{2}{*}{ Variable } & \multicolumn{2}{|c|}{ Sampling site } & \multicolumn{2}{|c|}{ P. perniciosus } & \multicolumn{2}{|c|}{ P. ariasi } \\
\hline & $\begin{array}{l}\text { Number of } \\
\text { sampling stations }\end{array}$ & $\begin{array}{c}\text { Percent } \\
\text { of stations }\end{array}$ & $\operatorname{IRR}^{\mathrm{a}}(95 \% \mathrm{CI})^{\mathrm{b}}$ & P-value & $\operatorname{IRR}^{\mathrm{a}}(95 \% \mathrm{CI})^{\mathrm{b}}$ & P-value \\
\hline \multicolumn{7}{|l|}{ Sheltered } \\
\hline Not sheltered & 267 & $79 \%$ & Ref. category & & Ref. category & \\
\hline Sheltered & 42 & $12 \%$ & $0.81(0.34-1.87)$ & 0.609 & $0.64(0.23-1.79)$ & 0.399 \\
\hline Unsure & 30 & $9 \%$ & $0.54(0.20-1.48)$ & 0.236 & $0.65(0.20-2.15)$ & 0.487 \\
\hline \multicolumn{7}{|l|}{ Drain hole wall construction } \\
\hline Other & 39 & $12 \%$ & Ref. category & & Ref. category & \\
\hline Stone & 272 & $80 \%$ & $1.09(0.35-3.39)$ & 0.877 & $2.94(0.84-7.39)$ & 0.098 \\
\hline Brick & 28 & $8 \%$ & $1.10(0.31-3.92)$ & 0.880 & $1.41(0.29-6.68)$ & 0.662 \\
\hline \multicolumn{7}{|l|}{ Drain hole construction } \\
\hline Other & 7 & $2 \%$ & Ref. category & & Ref. category & \\
\hline Unlined & 179 & $53 \%$ & $3.67(0.47-28.68)$ & 0.212 & $8.60(0.46-160.52)$ & 0.148 \\
\hline Brick lined & 23 & $7 \%$ & $2.08(0.21-20.55)$ & 0.527 & $4.88(0.20-114.54)$ & 0.322 \\
\hline Cement pipe & 61 & $18 \%$ & $5.85(0.70-48.75)$ & 0.101 & $4.31(0.21-86.30)$ & 0.338 \\
\hline Plastic pipe & 69 & $20 \%$ & $3.87(0.47-31.93)$ & 0.206 & $3.97(0.20-78.81)$ & 0.363 \\
\hline \multicolumn{7}{|l|}{ Hole interior } \\
\hline Other (bare and other) & 10 & $3 \%$ & Ref. category & & Ref. category & \\
\hline Dust & 264 & $78 \%$ & $1.33(0.25-8.88)$ & 0.730 & $0.51(0.07-3.34)$ & 0.482 \\
\hline Dust with vegetation & 36 & $11 \%$ & $0.90(0.18-6.89)$ & 0.904 & $0.48(0.05-3.95)$ & 0.497 \\
\hline Soil with vegetation & 29 & $8 \%$ & $0.37(0.05-2.48)$ & 0.308 & $0.30(0.03-2.65)$ & 0.277 \\
\hline \multicolumn{7}{|l|}{ Wall vegetation } \\
\hline No & 266 & $78 \%$ & Ref. category & & Ref. category & \\
\hline Yes & 73 & $22 \%$ & $0.86(0.43-1.69)$ & 0.665 & $2.90(1.36-6.15)$ & 0.005 \\
\hline \multicolumn{7}{|l|}{ Natural park } \\
\hline No & 269 & $79 \%$ & Ref. category & & Ref. category & \\
\hline Yes & 70 & $21 \%$ & $0.10(0.05-0.22)$ & $<0.001$ & $3.24(1.52-6.90)$ & 0.002 \\
\hline \multicolumn{7}{|l|}{ General environment } \\
\hline Other settlement & 44 & $13 \%$ & Ref. category & & Ref. category & \\
\hline Rural agriculture and forestry & 106 & $31 \%$ & $4.37(1.77-10.74)$ & 0.001 & $5.44(1.83-16.17)$ & 0.002 \\
\hline Rural village & 189 & $56 \%$ & $1.61(0.69-3.76)$ & 0.263 & $1.74(0.61-4.69)$ & 0.292 \\
\hline \multicolumn{7}{|l|}{ Adjacent natural vegetation } \\
\hline None & 31 & $9 \%$ & Ref. category & & Ref. category & \\
\hline Mountain pine & 17 & $5 \%$ & $0.40(0.08-1.95)$ & 0.527 & $7.43(1.43-38.39)$ & 0.016 \\
\hline Oak & 86 & $26 \%$ & $2.12(0.75-6.01)$ & 0.154 & $3.42(1.02-11.41)$ & 0.045 \\
\hline Aleppo pine & 31 & $9 \%$ & $5.20(1.50-18.02)$ & 0.009 & $1.29(0.29-5.68)$ & 0.727 \\
\hline Garrigue shrubs & 119 & $35 \%$ & $4.57(1.68-12.43)$ & 0.003 & $1.18(0.36-3.88)$ & 0.775 \\
\hline Valley alder & 31 & $9 \%$ & $1.14(0.32-4.05)$ & 0.837 & $2.92(0.69-12.22)$ & 0.140 \\
\hline Other & 24 & $7 \%$ & $0.87(0.22-3.43)$ & 0.844 & $0.07(0.00-1.13)$ & 0.061 \\
\hline \multicolumn{7}{|l|}{ Corine land cover } \\
\hline Rural, industrial/commercial area & 42 & $12 \%$ & Ref. category & & Ref. category & \\
\hline Arable & 189 & $56 \%$ & $5.47(2.30-12.98)$ & $<0.001$ & 3.57 (1.08-11.72) & 0.035 \\
\hline Pasture & 37 & $11 \%$ & $1.16(0.37-3.67)$ & 0.792 & $22.06(5.68-89.88)$ & $<0.001$ \\
\hline Garrigue shrubs & 27 & $8 \%$ & $2.18(0.63-7.50)$ & 0.212 & $5.52(1.21-25.15)$ & 0.027 \\
\hline Forestry & 44 & $13 \%$ & $1.59(0.53-4.73)$ & 0.402 & $13.10(3.39-50.53)$ & $<0.001$ \\
\hline
\end{tabular}




\begin{tabular}{|c|c|c|c|c|c|c|}
\hline \multirow[b]{2}{*}{ Variable } & \multicolumn{2}{|c|}{ Sampling site } & \multicolumn{2}{|c|}{ P. perniciosus } & \multicolumn{2}{|c|}{ P. ariasi } \\
\hline & $\begin{array}{l}\text { Number of } \\
\text { sampling stations }\end{array}$ & $\begin{array}{c}\text { Percent } \\
\text { of stations }\end{array}$ & $\operatorname{IRR}^{\mathrm{a}}(95 \% \mathrm{CI})^{\mathrm{b}}$ & P-value & $\operatorname{IRR}^{\mathrm{a}}(95 \% \mathrm{CI})^{\mathrm{b}}$ & P-value \\
\hline \multicolumn{7}{|l|}{ Dogs } \\
\hline Not seen & 230 & $68 \%$ & Ref. category & & Ref. category & \\
\hline Seen & 109 & $32 \%$ & $1.41(0.78-2.55)$ & 0.252 & $0.81(0.40-1-65)$ & 0.576 \\
\hline \multicolumn{7}{|l|}{ Cats } \\
\hline Not seen & 291 & $86 \%$ & Ref. category & & Ref. category & \\
\hline Seen & 48 & $14 \%$ & $1.31(0.58-2.89)$ & 0.510 & $0.68(0.26-1.77)$ & 0.428 \\
\hline \multicolumn{7}{|c|}{ Farm animals ${ }^{\mathrm{d}}$} \\
\hline Not seen & 265 & $78 \%$ & Ref. category & & Ref. category & \\
\hline Seen & 74 & $2 \%$ & $1.91(0.98-3.70)$ & 0.056 & $2.04(0.94-4.41)$ & 0.068 \\
\hline \multicolumn{7}{|l|}{$\operatorname{Birds}^{e}$} \\
\hline Not seen & 273 & $81 \%$ & Ref. category & & Ref. category & \\
\hline Seen & 66 & $19 \%$ & $1.63(0.81-3.28)$ & 0.166 & $0.55(0.23-1.29)$ & 0.170 \\
\hline
\end{tabular}

*Interquartile range (IQR); * "Standard deviation (SD); ancidence Risk Ratio; '95\% Confidence Interval; "Variable used as continuous in the model (for these variables, number is substituted by mean (with minimum and maximum values in brackets) and \% by the IQR or, alternatively, the SD; ${ }^{\mathrm{d}}$ Horses, cattle, sheep, pigs, goats; ${ }^{\circ}$ Chickens, ducks, pigeons and other large birds. Variables with a P-value $\leq 0.05$ were considered significant. 